\title{
The Six Ages of the World and Biblical Genealogy in Anglo-Saxon Encyclopaedic Notes
}

\author{
John Joseph Gallagher ${ }^{1}[$
}

Accepted: 3 May 2021 / Published online: 13 July 2021

(C) The Author(s) 2021

\begin{abstract}
In the early medieval period, history was commonly organised into six epochs lasting roughly one thousand years each, according to certain calculations of the world's age. The idea of the six ages emerged from and was consolidated by allegorical interpretations of the Hexameron in which the material endurance of the world was thought to mirror the initial length of its Creation. This historical schematisation enjoyed widespread currency in Anglo-Saxon England, even after Bede had proved that the world was not, in fact, approaching 6,000 years. This article analyses how the topos of the six ages is used and adapted within a hitherto understudied group of related encyclopaedic notes in three Anglo-Saxon manuscripts. How these texts relate to and differ from the wider corpus of encyclopaedic texts on this subject is also charted. The following study investigates the ways in which encyclopaedic texts on the six ages were adapted, expanded and transmitted, and the religious and political motivations driving such changes. This article offers the first in-depth analysis of this particular group of texts, foregrounding the sophistication of micro-texts that explain the six ages. Overall, this study emphasises the pedagogical, theological and historiographical applications of this concept in early medieval English thought.
\end{abstract}

Keywords Encyclopaedic notes $\cdot$ Sex aetates mundi $\cdot$ Transmission $\cdot$ Genealogy Chronology $\cdot$ Eschatology

\section{Introduction}

Outlining the ages of the world and their biblical parameters was an abiding intellectual and spiritual concern throughout the early medieval period in England. The sixfold schematisation of biblical and world history constituted the defining framework of early medieval historiography, chronology and computus. Therefore, unsurprisingly, a considerable number of Old English and Latin texts from early medieval

John Joseph Gallagher

john.gallagher@ucd.ie

1 School of English, Drama and Film, University College Dublin, Dublin, Ireland 
England are concerned with outlining this commonplace schematisation of history in easily digestible formats. ${ }^{1}$ The following study considers an encyclopaedic Old English note on the six ages of the world that is appended to Cambridge, Corpus Christi College 178 at p. 458, and its expanded macaronic Old English-Latin forms in Cambridge, Corpus Christi College 201, pp. 9-10 and Oxford, Bodleian Library, Hatton 113, fols. 3r-4r. This article focuses on the authorship, genre and function of these versions of the text. The origins and transmission of this note-and the theological, eschatological and polemical motivations behind both its composition and, in particular, its focus on Christ's genealogy — are the subject of the following discussion.

\section{CCCC 178}

The first part of the note in CCCC 178 presents the standard Augustinian-Isidorean tabulation for the six ages of the world. ${ }^{2}$ The note also includes the seventh eschatological age that follows the passing of this life. The information provided in this note is fairly typical of definitions of the sex aetates mundi which might account for the scant scholarly attention this text has received until now. ${ }^{3}$ A noteworthy feature of the shorter text in CCCC 178 is its inclusion of the seventh eschatological and anagogical age to come. Listing this post-temporal age goes beyond the theologically-limited confines of short encyclopaedic and explanatory texts. Indeed, the scripturally-based injunction that God alone knows when the end will come aims to counteract the difficulty of presenting a theologically complex topic like this in such laconic terms. ${ }^{4}$ The first section of the note briefly summarises the correspondence between the Hexameron and the six ages of the world, and the first Sabbath and the seventh age of the world to come. The correlation between the first week of biblical history and the subsequent six millennia of history emerges from exegesis of Psalm 89, 4, and its New Testament reflex in 2 Peter 3, 8, in which a day is likened to a thousand years. The second section tersely summarises the six ages of the world by providing the names of the biblical figures and events that bookend each era, and gestures to the seventh age.

A Latin version or analogue of the second part of this note, the sections that outline the ages by reference to their defining figures and events, is found in London, British Library, Cotton Tiberius A. iii, fols. 43v-44r. The codicological context of the note is encyclopaedic, occurring alongside notes on fasting, the Virgin and Old Testament figures. The note in CCCC 178 and that in Cotton Tiberius A. iii both share similar codicological arrangements, occurring in manuscripts containing

\footnotetext{
1 See Table 1.

2 The text of the Old English note in CCCC 178 is printed in Napier (1883, 311-312), Estes (2012, 647).

3 Tristram (1985) discusses Napier LXII, but not its shorter form in CCCC 178. Clayton's study of Flfric's De auguriis (2005, 376-394) provides a relevant framework for understanding how texts are adapted and augmented within changing manuscript contexts.

4 Based on Matthew 24, 36.
} 
Table 1 Anglo-Saxon encyclopaedic notes on the six ages

\begin{tabular}{|c|c|c|c|c|}
\hline $\begin{array}{l}\text { Textual } \\
\text { group }\end{array}$ & Manuscript & Schematisation & Details & $\begin{array}{l}\text { Date of } \\
\text { manuscript/ } \\
\text { additions }\end{array}$ \\
\hline \multirow[t]{4}{*}{ Group 1} & $\begin{array}{l}\text { Cambridge, Corpus } \\
\text { Christi College } 178\end{array}$ & \multirow{4}{*}{$\begin{array}{l}\text { Adam to Noe, Noe to } \\
\text { Abraham, Abraham } \\
\text { to David, David } \\
\text { to the Babylonian } \\
\text { Captivity/Josias, the } \\
\text { Babylonian Captiv- } \\
\text { ity/Josias to Christ, } \\
\text { Christ until the End } \\
\text { of Time }\end{array}$} & \multirow{3}{*}{$\begin{array}{l}\text { OE outline } \\
\text { OE outline; Latin geneal- } \\
\text { ogy }\end{array}$} & $1000 \times 1050$ \\
\hline & $\begin{array}{l}\text { Cambridge, Corpus } \\
\text { Christi College } 201\end{array}$ & & & $1040 \times 1060$ \\
\hline & $\begin{array}{l}\text { Oxford, Bodleian Library, } \\
\text { Hatton } 113\end{array}$ & & & $1063 \times 1083$ \\
\hline & $\begin{array}{l}\text { London, British Library, } \\
\text { Cotton Tiberius A. iii }\end{array}$ & & $\begin{array}{l}\text { Latin version of the } \mathrm{OE} \\
\text { above with variation }\end{array}$ & $1040 \times 1060$ \\
\hline \multirow[t]{4}{*}{ Group 2} & $\begin{array}{l}\text { Cambridge, Corpus } \\
\text { Christi College } 183\end{array}$ & \multirow{4}{*}{$\begin{array}{l}\text { Adam to Noe, Noe to } \\
\text { Abraham, Abraham } \\
\text { to David, David to } \\
\text { the Babylonian Cap- } \\
\text { tivity, the Babylonian } \\
\text { Captivity to Christ, } \\
\text { Christ until the End } \\
\text { of Time } \\
\text { Additional section } \\
\text { from De temporibus } \\
\text { including the seventh } \\
\text { and eighth eschato- } \\
\text { logical ages }\end{array}$} & \multirow{4}{*}{$\begin{array}{l}\text { Duration of each age; } \\
\text { followed by Bede, } \\
\text { De temporibus, xvi } \\
\text { and notes on related } \\
\text { chronological, numero- } \\
\text { logical, metrological } \\
\text { and biblical encyclo- } \\
\text { paedic notes addressing } \\
\text { such topics as the ages } \\
\text { of man, dimensions of } \\
\text { the Temple, St Peter's } \\
\text { Basilica and the Hex- } \\
\text { ameron }\end{array}$} & $834 \times 839$ \\
\hline & $\begin{array}{l}\text { Cambridge, Corpus } \\
\text { Christi College } 320\end{array}$ & & & $950 \times 999$ \\
\hline & $\begin{array}{l}\text { London, British Library, } \\
\text { Cotton Regius B. v }\end{array}$ & & & $990 \times 1099$ \\
\hline & $\begin{array}{l}\text { Paris, Bibliothèque } \\
\text { nationale de France, lat. } \\
2825\end{array}$ & & & $900 \times 1099$ \\
\hline \multirow[t]{3}{*}{ Group 3} & $\begin{array}{l}\text { London, British Library, } \\
\text { Stowe } 944\end{array}$ & \multirow[t]{3}{*}{$\begin{array}{l}\text { Adam to Noe, Noe to } \\
\text { Abraham, Abraham } \\
\text { to Moses, Moses } \\
\text { to David, David to } \\
\text { Christ }\end{array}$} & $\begin{array}{l}\text { (1) Macaronic text } \\
\text { detailing the duration } \\
\text { of each age; and (2) the } \\
\text { duration from Creation } \\
\text { to Christ's Advent, } \\
\text { from Creation to the } \\
\text { Passion, the duration } \\
\text { from Christ's baptism } \\
\text { to His Passion and the } \\
\text { age of the Virgin at } \\
\text { various stages }\end{array}$ & 1031 \\
\hline & $\begin{array}{l}\text { London, British Library, } \\
\text { Arundel } 60\end{array}$ & & $\begin{array}{l}\text { Contains part } 1 \text { of the } \\
\text { text of Stowe } 944 \text { only }\end{array}$ & $1050 \times 1099$ \\
\hline & $\begin{array}{l}\text { London, British Library, } \\
\text { Cotton Caligula A. xv }\end{array}$ & & $\begin{array}{l}\text { OE version of the text of } \\
\text { Stowe } 944\end{array}$ & $900 \times 1099$ \\
\hline Group 4 & $\begin{array}{l}\text { London, British Library, } \\
\text { Harley } 3271\end{array}$ & $\begin{array}{l}\text { Adam and Eve to the } \\
\text { Flood, the Flood to } \\
\text { Abraham, Abraham } \\
\text { to Moses and the } \\
\text { Flight from Egypt, } \\
\text { Moses to Solomon } \\
\text { and the Temple, } \\
\text { Temple to Christ, } \\
\text { Christ to present day }\end{array}$ & $\begin{array}{l}\text { Duration of each age; } \\
\text { interpolated note fol- } \\
\text { lowing the third age on } \\
\text { the Temple in Jerusa- } \\
\text { lem; various calcula- } \\
\text { tions of the duration } \\
\text { from Creation to the } \\
\text { foundation of Rome, } \\
\text { from the foundation } \\
\text { of Rome to Christ and } \\
\text { from Creation to the } \\
\text { present day }\end{array}$ & $1000 \times 1050$ \\
\hline
\end{tabular}


Table 1 (continued)

\begin{tabular}{ll}
$\begin{array}{l}\text { Textual } \\
\text { group }\end{array}$ & Manuscript \\
\hline & $\begin{array}{r}\text { London, British Library, } \\
\text { Cotton Vespasian D. vi }\end{array}$
\end{tabular}

Indi- $\quad$ London, British Library, vidual notes

\section{Cotton Tiberius C.}

London, British Library,

Cotton Vespasian B. vi

London, British Library, Cotton Nero A. ii

Oxford, St John's College 17
Creation to Noe, Noe to Abraham, Abraham to Moses, Moses to Advent, Advent to the End of the World

Adam to Flood, Flood to Abraham, Abraham to Moses, Moses to Solomon, Solomon to Darius, Darius to Tiberius

Creation to Flood, Flood to Nativity, Abraham to Flight from Egypt, Flight to the First Temple of Solomon, Solomon to Second Temple, Second Temple to Passion, Tiberius to Passion

Adam to Flood, Flood to Abraham, Abraham to Nativity
Date of

manuscript/

additions

Similar text to Harley

$940 \times 999$

3271 but omits the note on the Temple with minor variations thereafter

Duration of each age; begins with calculation of the duration from Nativity to Passion; also includes calculations of duration from Creation to the sacrifice of the lamb (by Abraham), from Creation to the Advent and from Creation to Passion

Duration of each age.

$804 \times 814$ Found within a group of encyclopaedic notes identical to that accompanying the six ages note in Group 2; the note on the six ages in this group was replaced in Vespasian B. vi with a less standard definition of the six ages

The duration between various touchstone figures are provided. NB: not defined as first or second age, etc.

$1070 \times 1100$

.

$1025 \times 1050$

Duration of each age 
monastic rules associated with the Benedictine reform-the Regula S. Benedicti (CCCC 178) and the Regularis Concordia (Cotton Tiberius A. iii). However, there are some key differences which make the relationship between these two texts difficult to discern. The note in Cotton Tiberius A. iii is Latin, not Old English and only features the second part of the CCCC 178 note. The manuscript of CCCC 178 seems to be marginally earlier $(1000 \times 1050)$ and from Worcester (Gneuss \& Lapidge, 2015, 65; Ker, 1957, 60), as discussed below, compared to Cotton Tiberius A. iii, which is dated $1040 \times 1060$ and traced to Christ Church, Canterbury (Gneuss \& Lapidge, 2015, 285; Ker, 1957, 240). It seems unlikely that the mid-century Latin text is a translation of the earlier Old English note in CCCC 178, as translation rarely operates in this direction; in all likelihood, both are descended from shared Latin materials available in both Canterbury and Worcester. ${ }^{5}$

The difference is greater in terms of substance: the Cotton Tiberius A. iii note defines the ages by exactly the same parameters as the CCCC 178 except for the sixth age which begins with the prophecy of John the Baptist in Cotton Tiberius A. iii, not with Christ's birth as in CCCC 178. This is highly unusual for texts on the six ages, and the only patristic authority to trace the start of the sixth age to the Baptiser is Augustine, in his In Ioannis Evangelium tractatus. It is not a common reference point within material dealing with the six ages. The two texts seem to share a source, but it is not possible to be certain about the precise nature of this relationship. The Cotton Tiberius A. iii note differs enough from that in CCCC 178 that it could be regarded as a related but ultimately separate text that is not pertinent to the present discussion. We can only be confident that encyclopaedic material on the six ages was circulated, adapted and repurposed in both Latin and Old English in the eleventh century.

\section{Napier LXII: Authorship}

The text of the note in CCCC 178 is identical to the opening two Old English sections of the anonymous 'homily' found in CCCC 201 and Hatton 113, hitherto known as Napier LXII, a text that was first attributed to Wulfstan of York by Arthur Napier in his edition of the Archbishop's homilies. ${ }^{6}$ Much earlier, Humfrey Wanley had not included the text in his list of Wulfstan homilies (Wanley, 1705, 140-143). Napier's decision to do so was probably influenced by the appearance of this text in both CCCC 201 and Hatton 113 immediately before the incipit 'incipiunt sermones lupi episcopi', which might have suggested to him that the note was also the work of Wulfstan especially since the material in the first part of CCCC 201 is thought to constitute a version of Wulfstan's Handbook, and given the general thematic overlap of material in this codex in terms of cosmology and chronology. ${ }^{7}$

\footnotetext{
${ }^{5}$ Cf. n. 18 below.

6 For the text of Napier LXII, see Napier (1883, 311-313).

7 CCCC 201, pp. 9-10; Hatton 113, fols. 3r-4r.
} 
Napier LXII differs from the text in CCCC 178 in that it contains a third Latin section of five parts which summarise the linea Christi, Christ's ancestry for each of the five ages up until the Incarnation and the start of the present sixth age. These Latin sections are not found in the text as it appears in CCCC 178 and represent a later addition to it, as discussed in more detail below.

Napier LXII was ascribed to Wulfstan by Napier probably because of its appearance in CCCC 201, a significant collection of Wulfstan's homilies. CCCC 178, including our note, was possibly extant in the library at Worcester during Wulfstan's episcopacy there and may have been known to him. The relationship between the two parts of CCCC 178, a collection of Ælfrician homilies and a bilingual Benedictine Rule followed by this note, is unclear; both were copied in the same period and were linked by the thirteenth century when the Tremulous Hand of Worcester glossed its contents. There is thematic overlap between biblical and world chronology as addressed in this note and the opening contents of part I of CCCC 178, Ælfric's Hexameron and his Genesis-based Interrogationes Sigewulfi. Without further evidence as to when the two parts became connected, we cannot entertain the prospect that this note was chosen to complement this Ælfrician-Benedictine compendium or that it was associated with Ælfric. The importance of reading a text within its manuscript context is, nonetheless, apparent. ${ }^{8}$ The text was copied into Hatton 113 by Wulfgeat for use by Wulfstan of Worcester (1062-1095) and it is highly likely that he was familiar with this note (Lionarons, 2010, 12-13). Napier LXII occupies an integral position in both CCCC 201 and Hatton 113 where it was included as part of the designed plan for these compendia.

Wulfstan's authorship of Napier LXII was first dismissed by Max Förster in 1925 who referred to the form of the text in CCCC 178 and Hatton 113 as authored by 'pseudo-Wulfstan' (Förster, 1925, 187). Napier LXII was not regarded as being authored by Wulfstan by Karl Jost in his significant and defining study of the Archbishop's works (Jost, 1950). ${ }^{9}$ Dorothy Bethurum rejected Wulfstan's authorship of Napier LXII as spurious in her edition of the Archbishop's homilies (Bethurum, 1957, 43). Bethurum does not explicitly explain her rejection of Napier LXII, but she most likely dismissed it for two reasons: firstly, it is not homiletic in tone and did not, therefore, qualify for inclusion in her edition; and secondly and most significantly, Napier LXII does not satisfy the criteria of Wulfstanian style, vocabulary and syntax that are essential to her and later editors' categorisation of bona fide Wulfstanian texts, as outlined in her edition (Bethurum, 1957, 87-98). The text was never the subject of substantial scholarly interest and, since Bethurum, has only been discussed in passing. ${ }^{10}$ While the greater part of Wulfstan's canon has been

\footnotetext{
${ }^{8}$ Recent insights offered by Foxhall-Forbes underscore the complexity of homiletic manuscript compendia such as Hatton 113. Cf. Foxhall-Forbes (2019, 29-57).

9 Jost, Wulfstanstudien, remains the foundational study of Wulfstan's canon, style and vocabulary.

10 Napier LXII is mentioned briefly in Michael Fox's discussion of Wulfstan's possible reuse of Ælfric (Fox, 2018, 269, n. 49). The place of Napier LXII within the canon is discussed in Sara Pons-Sanz's chapter on Wulfstan's canon and style, a helpful recent examination of this question (Pons-Sanz, 2007, 7-31). Daniel Anlezark remarks upon the thematic cohesion between the opening homilies of CCCC 201 (Anlezark, 2006, 66). Aaron Kleist notes Ker's identification of links between CCCC 178 and Hatton 113
} 
established, its parameters are not yet firmly fixed. ${ }^{11}$ No subsequent editors or critics of Wulfstan have sought to rehabilitate Napier LXII within the canon. ${ }^{12}$ This author agrees that the text does not come from Wulfstan's hand, but here I seek to provide the first detailed examination of the content and function of the note and its longer form, Napier LXII.

The correspondence between the shorter Old English note in CCCC 178 and the longer macaronic version of it in CCCC 201 and Hatton 113 was first recorded in print by Ker $(1957,64 ; 83 ; 391)$. While the note in CCCC 178 is typical of encyclopaedic notes on the six ages, its longer form is noteworthy in terms of its treatment of the six ages, its bilingualism and its potential relationship to contemporary political and theological concerns. ${ }^{13}$ The substance of the three forms of the text and the relationship between these versions have not received the detailed discussion they deserve. ${ }^{14}$ While Napier LXII (and by implication CCCC 178) is no longer considered to be by Wulfstan, there has been no discussion of what, in fact, this text constitutes in both its forms or of what function it might have held-questions that this study will attempt to answer.

\section{Genre}

Napier's inclusion of the text in his edition of Wulfstan's homilies raises questions about the genre of the text. Neither Napier LXII nor the shorter version in CCCC 178 could be considered a homily. The text is generically encyclopaedic and educational, rather than homiletic or sermonising. It is difficult to imagine an occasion in the liturgical year where simply summarising the ages of the world, as this text does, and systematically enumerating the biblical figures that define each age, would be entirely appropriate to the lectionary or in any way spiritually edifying without further in-depth exegesis.

That is not to say that the theme of the six ages is inappropriate to the pulpit. Bede addresses the six ages on at least three occasions in his homiletic corpus: Homilia 1,

\footnotetext{
Footnote 10 (continued)

in terms of Ælfric's Catholic Homilies 1, 21 and Napier LXII, pointing to the relationship between these homiletic codices (Kleist, 2009, 394, n. 74).

11 Jost's edition of Wulfstan's homilies included a list of texts he regarded as genuine Wulfstanian compositions $(1950,116)$. More recently, Jonathan Wilcox has outlined the texts he considers to be authored by Wulfstan, including composite reworkings of homilies and newly identified material (Wilcox, 1992, 199-217, in particular 200-201). Concerning Wulfstan's reception, Wilcox discusses the attribution and recycling of Wulfstan's homilies in the eleventh century (Wilcox, 2000, 83-97). Winfried Rudolf has also examined the question of Wulfstan's canon (Rudolf, 2001, 107-149). Overall, Joyce Tally Lionarons's chapter on re-establishing the Wulfstanian homiletic canon provides the most recent and up-todate overview of scholarship on the canon and its contents (Lionarons, 2010, 23-42).

12 Kathryn Powell (pace) refers to Napier LXII as a text authored by Wulfstan, probably because she is working with the only edition of the text by Napier, which predates Förster and Bethurum's dismissal of the text from the canon (Powell, 2008, 156-157).

13 See Table 1.

14 The note in CCCC 178 was transcribed and discussed in short by Schröer (1888, xix-xxi).
} 
14 consists mostly of an extended allegorisation of the six hydria used in the miracle at Cana as the six ages and their spiritual characteristics; Homilia 2, 7 on the Easter Vigil relates the sixth, seventh and eight ages of the world allegorically to Christ's death on the sixth day, rest on the seventh and resurrection on the eighth day of the week; and Homilia 2, 24, the first homily for the dedication of the Abbey Church of St Paul, Jarrow, draws mystical parallels between the construction of the Temple in seven years and its dedication in the eighth year to the development of the Church up until the seventh age and the anticipated felicity of the world to come, that is, the eighth age. Similarly, ÆCHom II, 4, dominica II post Aepiphania Domini, on the Gospel pericope concerning the Marriage Feast at Cana, John 2, 1-11, allegorises the six jars as the six ages of the world (Godden, 1979, 29-40; Thorpe, 1846, 54-72). Here, Ælfric outlines the six ages before providing a detailed examination of each age. As observed by Joyce Hill, 'the characterisation of the six ages of the world accounts for more than half of the text' (Hill, 1992, 217). These homiletic uses of the sex aetates mundi occur primarily within allegorical meditations and entreaties on eschatological and mystical themes that point the audience towards spiritual reflection and discipline. By comparison, the treatment of the six ages in Napier LXII is categorically factual and encyclopaedic, rather than homiletic.

This account of the ages lacks any of the features that commonly mark a homily or sermon such as an address, an exhortation to faith or morality or sustained scriptural or thematic exposition. The text is analogous to encyclopaedic notes or micro-texts and probably held a similar function. ${ }^{15}$ It is likely an educational reference item that was consulted by preachers, scholars or educated ecclesiastics as a précis of the sex aetates mundi schema in its shorter form or as a comprehensive delineation of it in its longer form. The text comprises a summary of this crucial intellectual and spiritual concept that may have been used as a simple go-to account on the subject of world chronology and biblical history. The shorter text in CCCC 178 resembles more closely the kind of encyclopaedic notes found in CCCC 320 in its terse, direct and accessible reference format. As Dekker observes, a text such as this is difficult to categorise due the heterogeneity of these kinds of texts that relay 'factual information of an abbreviated or condensed nature about topics that can be classified as encyclopaedic' (Dekker, 2012, 65; cf. also Dekker, 2013, 95-130). The three manuscript versions of the text are referred to by various titles, reflecting the difficulty posed in categorising such texts generically: CCCC 178 'Seven Ages of the World (encyclopaedic note)'; CCCC 201 'On the Seven Ages of the World'; and Hatton 113 'a treatise On the Seven Ages of the World' (Gneuss \& Lapidge, 2015, $65 ; 83 ; 484) .{ }^{16}$ This account of the six ages fits most comfortably within the genre of didactic, encyclopaedic texts defined by Dekker (2007, 310-313). ${ }^{17}$

\footnotetext{
15 Cf. Dekker (2019, 203-224); Lenker and Kornexl (eds.) (2019).

16 References to Gneuss and Lapidge Handlist here refer to page numbers, rather than to the numerical titles of manuscripts.

17 Dekker provides a schema for the categorisation of encyclopaedic notes as a distinct functional type of prose text in his study of their organisation and composition (Dekker, 2013, 95-130); M. J. Toswell investigates the problem of categorising prose and poetic texts with respect to the taxonomy devised by Angus Cameron for the Dictionary of Old English (Toswell, 2020, 229-241).
} 


\section{Date and Provenance}

The manuscript evidence confirms that CCCC 178 is the eldest witness of the text and is dated by both Ker and Gneuss and Lapidge to the first half of the eleventh century, $1000 \times 1050$ (Ker, 1957, 60; Gneuss \& Lapidge, 2015, 63). CCCC 201 is dated to the middle of the eleventh century, $1040 \times 1060$, by Ker and to the first half or middle of the century by Gneuss and Lapidge, $1000 \times 1050$ or $1040 \times 1060$ (Ker, 1957, 82; Gneuss \& Lapidge, 2015, 83). Hatton 113 is dated by Ker to the third quarter of the eleventh century and to the second half, specifically $1063 \times 1083$, by Gneuss and Lapidge (Ker, 1957, 391; Gneuss \& Lapidge, 2015, 484). These dates for CCCC 178 could be conservative and the text may be from the earlier part of the first half of the eleventh century. The note is a later addition, but does not seem to be much later than the copies of other texts in the manuscript to which it is appended. Ker suggests that the note is a later addition to a blank leaf (Ker, 1957, 64), linking the note to Hatton 113 in the second half of the eleventh century-1050×1099, even though he dates Hatton 113 to $1050 \times 1075$ only (Ker, 1957, 391). One manuscript must predate the other, and it seems likely that CCCC 178 is the earlier work; while the note might be a later addition, it does not seem to be much later than the other works in the codex and is possibly a contemporary addition to conclude the compilation. It is written in a delicate, attractive and neat Anglo-Saxon minuscule that makes full use of the space it occupies. The availability of blank space following the note indicates that the text has not been truncated.

The dates given for the manuscripts and the textual evidence of augmentation into a longer macaronic version seem to confirm that the Old English note in CCCC 178 is the older and, perhaps, original authorial form of the text. ${ }^{18}$ Since both CCCC 201 and Hatton 113 contain word for word the expanded version of the text, then it follows that there was an intermediary, extended version between CCCC 178 and its later two witnesses. That is, CCCC 201 and Hatton 113 are both copied from an intermediary expanded version of the CCCC 178 note, since both follow one another so closely. The spelling and palaeographical variation between CCCC 178, on the one hand, and the other two versions which follow one another closely, on the other, also provide evidence for an earlier date for the shorter text and the idea of an intermediary version. The augmentation may have taken place at Worcester since both CCCC 178 (part II, Gneuss \& Lapidge no. 55) and Hatton 113 can be traced there. ${ }^{19}$ The provenance of CCCC 201 is less certain. A Worcester origin is proposed for all three manuscripts by $\operatorname{Ker}(1957,64)$ on the basis that the hands are typical of Worcester, but CCCC 201 is specifically assigned to New Minster, Winchester, by Gneuss and Lapidge $(2015,83)$ and more cautiously to Winchester by Budny (1997,

\footnotetext{
18 Correspondence with the Cotton Tiberius A. iii note could suggest an original Latin version from which both texts descended. However, the Tiberius note is sufficiently different in its description of the ages and contains only half of the CCCC 178 note, indicating that it is a separate text that happens to adhere, largely, to the standard Augustinian-Isidorean schematisation of the six ages.

19 See Stoneman (1987, 78-82), on marginalia in CCCC 178 and Hatton 113 attributed to Coleman, chancellor of Wulfstan of Worcester.
} 
477). From these dates, we can infer how the text evolved in the first three quarters of the eleventh century from its earlier and original form in CCCC 178 to its longer adapted version in CCCC 201 and Hatton 113. Given the provenance of these manuscripts, it is likely that the text's longer form was adapted and transmitted within the Worcester scriptorium.

\section{Language, Sources and Content}

The additional sections of Napier LXII not found in CCCC 178 are Latin and form a later augmentation of the Old English note into a longer, bilingual reference text. Dekker has noted that it is 'remarkably rare for encyclopaedic notes to be macaronic, i.e., written in both Latin and Old English' (Dekker, 2012, 75). Indeed, Napier LXII is the only Anglo-Saxon encyclopaedic note to mix languages in this way (Dekker, 2012, 75). The note in London, British Library, Stowe 944-and the partial version of this text in London, British Library, Arundel 60-is the only other macaronic note on the six ages from Anglo-Saxon England, but it does not alternate to the same degree as Napier LXII since its Latin sections are minimal. ${ }^{20}$ Macaronic alternation is also a feature of the prosimetric Middle Irish-Latin Sex aetates mundi (Ó Cróinín, 1983); although this is a literary composition, unlike Napier LXII, it is, nonetheless, encyclopaedic in terms of the breadth and learnedness of the exegetical knowledge it assembles. It is also highly unusual for a metrical and literary text to be macaronic. As Dekker suggests, language switching is rare except in the context of glossing or grammatical works (Dekker, 2012, 75). ${ }^{21}$ No other encyclopaedic notes from AngloSaxon England alternate between Latin and Old English in this fashion. The raison d'être for the bilingualism of Napier LXII, the notes in Stowe 944 and Arundel 60 and the Irish Sex aetates mundi is the engagement of these texts with Latin biblical subjects and lemmata which are germane to the topic of the six ages of the world.

The Latin sections comprise five summaries of the biblical generations for the five ages of the world that precede the contemporary, post-biblical sixth age: Adam-Noah, Noah-Abraham, Abraham-David, David-Josias and Josias-Christ. The third, fourth and fifth age are excerpted from Matthew 1-a genealogical prolegomenon to the Four Gospels and New Testament overall. However, since Matthew traces Jesus' ancestry from Abraham only, the compiler of Napier LXII turned to Luke, which provides the only other genealogy for Christ in the Gospels, for the remaining generations between Abraham and Adam. The section on the first age from Adam to Noe takes the names and offspring of the patriarchs from Luke 3, 36-38, while the section on the second age from Noe to Abraham takes its detail from Luke 3, 34-36. The generations of the third through fifth ages are taken from Matthew 1, 1-6, 6-10 and 11-16 respectively. The Matthean genealogy follows the patrilineage of Christ through Joseph's ancestry, beginning with Abraham (the start

\footnotetext{
20 See Table 1, Group 3.

21 Elements of Old English frequently appear in Latin notes, as indicated by Dekker (2012, 76), but these are not macaronic or bilingual to the same degree as the text at hand.
} 
of the third age) and working forwards through David to Joseph, the Virgin Mary and Christ. The Lukan genealogy enumerates Christ's ancestry by tracing His lineage backwards from Joseph to Adam and God-Christ's coeternal Father. We can be fairly certain that our redactor worked directly from the text of Luke for the second age, rather than the Vulgate Genesis, because of the appearance of the postdiluvian Cainan-a figure who occurs only in the Gospel of Luke and the Septuagint Genesis on which it draws. This disputable textual feature is discussed by Bede in De temporum ratione (V, s.v. anno mundi 1693; Wallis, 1999, 163). The conclusion of the section on the fifth age quotes Matthew 1, 16 verbatim, confirming that these final three sections are an abridgement of Matthew.

The compiler began with the Matthean genealogy and turned to Luke to fill in the gaps. This required rearrangement of the Lukan material, changing its retrograde linear patriline structure from Joseph to Adam into a prograde "chronogenealogical' order to mirror the Matthean structure. Napier LXII employs the verb genuit found in Matthew, rather than qui fuit of Luke, reinforcing the idea that the text is an expanded abridgement of the Matthean genealogy. The redactor of Napier LXII would have had to reorganise the formula of the Lukan material from Y qui fuit $\mathrm{X}$ ('who was [son] of') to $\mathrm{X}$ autem genuit $\mathrm{Y}$ ('and ... begat'). The genealogy of the Vulgate Genesis 5 (which presents precisely the same figures for the first age as Luke and Napier LXII) and of Genesis 11 also contain the genuit formula; however, reliance on Genesis is not necessary since the text's compiler could simply have extended the structure and phrasing of the Matthean genealogy to the Lukan material. As noted, the appearance of Cainan in the second age confirms reliance on the New Testament. The omission of the ages of the patriarchs, which is such a central characteristic of the Genesis genealogies as well as Isidore and Bede (discussed below), strengthens the argument for the use of New Testament sources only. ${ }^{22}$ Indeed, the rationale for the note's composition may have been to explicate the slightly perplexing genealogies of the Gospels by applying these to a well-known historiographical schematisation. Interestingly, the text of Hatton 113 names the offspring of Thare as 'Abram', Abraham's initial name in Genesis, showing a sensitivity to the form of the patriarch's name as it first appears in Genesis. However, this does not suggest the use of the Genesis 11 genealogy since the form 'Abram' does not feature there. The straightforwardness of the note and the fact that the author does not seem to use Genesis, Isidore or Bede directly suggests that the text consciously does not engage this morass of genealogical material, but chose to focus on the Gospels simpliciter.

This assemblage of biblical genealogies tells us three things: firstly, the compiler of the text was interested in the genealogy of Christ only and how Christ relates to the figures of the biblical past; secondly, the text's redactor was not interested in the age of the biblical figures mentioned or the length of an age; and

\footnotetext{
22 Sections of Genesis that could have been utilised include the genealogy of Cain's descendants in Genesis 4, 17-26; the enumeration of the line of Seth given in Genesis 5; the Table of Nations in Genesis 10 which provides an ethnography or origines gentium for the world (not strictly genealogical); and Genesis 11, 10-32 which lists the progeny of Sem down to Abraham.
} 
thirdly, the text's assembler afforded credence to biblical sources only in establishing the parameters of the six ages, and was not perturbed by the incongruities between these biblical lineages or drawn to exterior chronological material. The individual who expanded the text combined two vastly different and, indeed, conflicting genealogies for Christ; the two biblical genealogies agree only on the constituent members of the third age from Abraham to David. Thereafter, the genealogies diverge between David's sons Solomon, followed in Matthew, and Nathan, followed in Luke.

Outlining the biblical patriarchs and the number and names of their descendants is a staple feature of texts that elaborate the six ages such as Isidore's Etymologiae (V.38, De saeculis et aetibus; V.38, De descriptione temporum), Bede's related De temporibus (16) and his later, more detailed work, De temporum ratione (V). None of these central, canonical and widely-available reference works on the six ages describe the schema in the same way as Napier LXII, confirming that our AngloSaxon redactor independently composed the text's additional parts while working from biblical sources only. Isidore and Bede both enumerate the age of each biblical figure in an epoch and the precise number and age of their generations. Bede's works, in particular, are focused on calculating the length of each age, contrasting the numerical figures given in the Septuagint and Vulgate versions of the Bible. By contrast, Napier LXII assembles only the names of an age's defining figures.

None of the central texts that deal with the six ages and which were widely available for scholarly consultation in early medieval England show any overlap with the text at hand. Isidore and Bede follow the Vulgate tradition regarding Arfaxat's descendant Sala, while the Septuagint, Luke and Napier LXII insert an additional generation. It would not be possible to construct Christ's genealogy from either Isidore or Bede. While Christ's genealogy is given for the first two ages, the chronologies of Isidore and Bede become more comprehensive, enumerating biblical figures and events in world history, as is appropriate within a biblical-world chronology. Our author was undoubtedly aware of these seminal chronological works, but found them unwieldy or unserviceable for encyclopaedic purposes. The author foregoes these more expansive texts in favour of a direct explanation of the six ages that makes biblical generations of each age more manageable by focusing directly on the genealogy of Christ alone.

As well as disregarding up-to-date biblical textual criticism on Cainan evinced by Bede, Napier LXII rejects or does not engage with the most up-to-the-minute chronological scholarship of Bede. For example, following Bede's De temporum ratione, the number of generations for each of the ages became fixed to 10-10-14-14-14, while Napier follows the Gospel texts closely in tallying these as 10-12-14-14-14. By the ninth, tenth and eleventh centuries, the period in which encyclopaedic notes of this nature were written and circulated, Bede's chronological reckoning had become the standard. This encyclopaedic note eschews Bede's innovations in favour of a separate Gospel-based calculation of the sex aetates mundi. In this way, the text achieves its encyclopaedic purpose: it lays out this schema simply for those who do not wish to delve into the morass of Old Testament genealogical scholarship and chronological reckoning that so consumed Isidore, Bede and other chronologists and computists in the earlier medieval period. 
The composition of the genealogy suggests an author who is consciously selecting and adapting biblical genealogy, rather than working from an exemplum. The interest in compiling biblical lists of information in a compact and digested format indicates that the function of the text was encyclopaedic. The preservation of Latin shows us how biblical genealogy was best dealt with in Latin, as translating Latin biblical names into the vernacular would add more linguistic complexity to what was intended as a simple reference text. In the Old English Gospels, for example, the genealogy in Luke 3, 23-28 is omitted, suggesting that the translators found it difficult or irrelevant to translate the names. ${ }^{23}$ I agree with Dekker's suggestion that the genealogy is given in Latin because it 'reminded the compiler of the names from the Bible' (Dekker, 2012, 75). A précis of the concept is given in Old English alongside Latin catalogues of the linea Christi for each age that are lifted directly from the Bible. In one way, the text resembles biblical commentaries or homilies that provide vernacular explanations of Latin biblical pericopes that were usually cited in the case of biblical commentaries or read aloud liturgically or privately in the case of homilies. The additional sections provide a clear picture of the importance of concisely extracting and organising relevant information from several biblical sources. One observes, too, how encyclopaedic material was revised and augmented over time according to the need of later users.

\section{Royal Genealogies}

The text bears a resemblance to the corpus of the Anglo-Saxon royal genealogies, particularly the West Saxon pedigrees which are engaged with biblical genealogy. The centrality of pre-Christian figures such as Woden, Saxnot and Geat (no longer gods for the Anglo-Saxons by the time these genealogies were composed) within these texts communicates the Germanic origins of the Anglo-Saxons and confirms the descent of royal genealogies from earlier pre-Christian traditions. Biblical figures and genealogy, however, only feature in the pedigree of Æthelwulf, King of Wessex (s. 839-858), in which the king's ancestry is traced to Sceaf, an apocryphal, fourth, ark-born son of Noe, and onwards, by implication, to Adam and God (Hill, 1987, 379-383; Davis, 1992, 23-36). ${ }^{24}$ The West Saxon pedigrees are the only surviving genealogies that provide the stages above Geat, and the only pedigrees that contain biblical figures (Chambers, 1959, 201-203). Comparably, the Historia

\footnotetext{
23 The translation cuts off at Luke 1, 23 and a short summary indicating that there are 170 generations between Christ and Adam (Liuzza, 1994, 105). The Old English gloss to the Lindisfarne Gospels follows the Latin names of Matthew 1, inflecting the name Roboam-Roboas according to the Latin grammar (Skeat, 1874, 43).

24 The genealogies are printed in Chambers $(1959,195-203)$. The figure of Sceaf is variously recorded as Scyf and Scef in versions of the Textus Roffensis. He is recorded as Hrathra, Hrapraing and Scef in the Anglo-Saxon Chronicle (Swanton, 1996, 200); cf. Parker Chronicle, s.v. 855; Asser, in De rebus gestis Alfredi, traces Alfred's ancestry back to Noe via Seth (Adam's son) which appears to be an error. The genealogy of Æthelweard contains Scef who is not a son of Noe but who appeared from nowhere on the ship. Various other manuscripts of the pedigree trace the king's ancestry back to Sceafing son of Noe, Scef son of Noe, Sescef and Seseph (Chambers, 1959, 195-203). Cf. also Meaney (1989, 7-40).
} 
Brittonum, an earlier text preserved in later manuscript witnesses, traces the pedigree of Brutus back to Adam via Japeth. Given that Noe is the progenitor of all mankind, which shares the ancestry from Noe to Adam, it is not surprising that Æthelwulf's lineage is traced back to this figure alone. Similarly, the Table of Nations, which describes the ethnogenesis of all nations, would have invited genealogists and general scholars alike to identify a figure or group's origin with one of the generations of Noe. Interestingly, the genealogies terminate with Noe, indicating that the generations between Noe and Adam were not in dispute and easily accessible. It is, furthermore, noteworthy that an apocryphal character is used to connect these Germanic and biblical lineages. As Anne Redgate observes, Sceaf's origin in 'the saved world of the ark, rather than in the sinful world that preceded it' may have bestowed greater authority on the West Saxon kings $(2014,90)$. The fact that more royal genealogies do not attempt to integrate biblical genealogy betrays the original historical function of these texts as a means of legitimising pre-Christian Germanic kingship through biological links with ancestral figures (Hill, 1987, 381). Confirming biological links with biblical figures is not such a concern for Christian AngloSaxon kings, since these links are implicit in the Table of Nations which delineates the biblical origin of all nations and their kings.

\section{Function and Polemics}

Although we cannot suggest anything concrete concerning authorship or readership, we might ponder what such a text and its particular view of the six ages might have meant within the milieu of late Anglo-Saxon England in the eleventh century. Napier LXII is part of a considerable corpus of encyclopaedic notes on the six ages of the world that survives from Anglo-Saxon England (cf. Estes, 2012, 623-651). ${ }^{25}$ The six ages is the most recurring topic within the corpus of Anglo-Saxon encyclopaedic micro-texts. The present author has identified seventeen notes on the six ages: thirteen variations of four principal notes and a further four individual notes that occur in one version only. ${ }^{26}$ While an investigation of the various permutations of the six ages within these texts is beyond the scope of the study at hand, locating how Napier LXII operates within the corpus will help us to comprehend its motivations more fully. ${ }^{27}$

Notes in Groups 1 and 2 offer the standard Augustinian-Isidorean explanation of the six ages; the remaining notes deviate in less standard ways from this schema. Although it provides the orthodox outline of the ages, Group 1 is unique for its omission of the duration of each age compared to other notes in the corpus, all of

\footnotetext{
25 Arthur Napier and Max Förster collated many of these texts in their 1889 and 1925 articles respectively, and Hildegard Tristram lists the most of them in her study (Förster, 1925, 183-203; Napier, 1883, 1-10; Tristram, 1985).

26 See Table 1.

27 Anlezark's study of numbers in Harley 3271 reveals how complex individual numerological notes are and how fruitfully these texts can be studied within their manuscript context. Cf. Anlezark (2010, 137155).
} 
which detail the number of years in an age according to Septuagint or Vulgate calculations. This is, perhaps, less noteworthy within the short notes CCCC 178 and Cotton Tiberius A. iii, but is more striking in a longer text such as Napier LXII in which this topic could have been treated. As suggested above, Napier LXII is distinctive in providing the New Testament genealogies of Christ as the means of defining an era, while all other texts in the corpus advert to the Old Testament—or sources which do so-for the age of the patriarchs, the number of their generations and the duration of an age. In eschewing the temporal specifics of the schema, Napier LXII shifts focus from the complex quagmire of biblical calculations that define all other notes in this series towards a simplified schema focused on Christ. The motivation could arise from a desire for simplicity; even a highly diligent biblical scholar might not be able to arrive at the precise figures found in these notes without recourse to intermediate resources, given the variety inherent in biblical manuscripts at this time. Notes outlining the duration of an age are necessitated by the irregularities of the biblical textual tradition, but are also subject to its discrepancies. Napier LXII bypasses these issues by reorienting the focus to Gospel genealogies, arguably rendering it the most distinctive treatment of the six ages within this corpus of micro-texts.

The main difference between the text at hand and others in the corpus is the hemerological interest in calculating the precise length of each age exhibited in other texts of this type. Defining the precise duration of the ages could lead to millenarian expectations surrounding the end, a fairly widespread phenomenon at the turn of the millennium in England (Bremmer, 2003, 501-514; Cubitt, 2015, 27-52; Duncan, 1999, 15-23). The hemerological focus of all notes in the corpus outside of Group 1 hinders any meaningful spiritual understanding of the six ages or of history. In these texts, it is very much a case of not seeing the forest for the trees. Napier LXII builds on related shorter notes to provide a detailed exposition of the six ages, but one which points its readers to Christ, His second coming and the consummation of time in the world to come. This is, after all, the motivation for Augustine's engagement with the sex aetates mundi in De civitate Dei. Our note is distinct in its lack of interest in calculating the length of each age, even in its longer Latin additions. Napier LXII communicates a view of the world ages that implicitly and deftly conveys a denial of chiliasm and sabbatical millenarianism, that is, the expectation that AD 1000 will herald the end of the sixth age. It is certain that the note was redacted into its longer form in the eleventh century, thus its omission of the duration of each age is conspicuous. Bede, whose works on chronology were widely available for centuries before the eleventh century, presents the length of each age. The decisions of both our text's author and redactor to omit the length of the ages must, therefore, be deliberate and significant.

Bede's scholarship established that according to the Bible the world was 3,952 years old at the Incarnation, not 5,199 as was previously thought, thus diminishing the popular idea that the six ages of the world would last roughly 6,000 years - an understanding predicated on allegorical interpretations of the Hexameron. Nevertheless, calculating the duration of each age endured as a popular pedagogical activity in Anglo-Saxon England. The duration of an age had become typologically and allegorically meaningless thanks to Bede's reorientation of annus mundi. Napier LXII, however, negotiates the gordian knot of the world ages by 
foregoing the Old Testament, the age of the patriarchs and the number of their generations in favour of straightforward genealogical lists from the Gospels.

The shift of focus to Christ in Napier LXII, in the same way as the excursus on the Temple in Harley 3271, may have been motivated by eschatological concerns. Kathryn Powell has shown how annotations in CCCC 162 indicate how the eschatological and penitential aspects of Ælfric's Ash Wednesday homily (ÆLS [Ash Wed]) found renewed ideological relevance in the context of the Viking incursions (2008, 151-173). Our text on world ages is not concerned with the length or duration of individual ages and promotes Augustine's and Bede's idea of the seventh age as parallel to this age, not consecutive to it. The Babylonian desolation of Jerusalem is a key moment in the outline of the ages of the world and is mentioned in most texts on this subject. Josias is not commonly used to define the end of the fourth age or the beginning of the fifth. While the Old English section of our text refers to the heregang, the Latin sections of Napier LXII, however, are not interested in defining the end of the fourth age by reference to the exile, but by the biblical figures of this period. This is most interesting since the Latin sections are based on the Matthean genealogy, which does mention the exile. I would suggest that this omission shows the later augmentation of the text to be less concerned with defining the end of a period by the onslaught of invasion and could indicate a shift in eleventh-century eschatological thinking. Following the passing of the millennium and in the wake of Viking and Norman conflicts, our account pointed its eleventh-century readers to the fact that the eschaton is to be expected, but ought not to be definitively calculated. It also communicates that an end of an era ought not to be defined by invasion, turmoil or its duration. Malcolm Godden's argument that Wulfstan's eschatology evolved from a New Testament conception of impending apocalypse to an Old Testament understanding of the continual tribulation faced by God's chosen people has gained significant traction $(1994,130-163) .{ }^{28}$ To put it another way, eschatological thinking and preaching following the millennium became less concerned with the calculation of the precise length of each period and the interpretation of contemporary turmoil and more with spiritual reflection. Within the religious and intellectual climate of the eleventh century, a short explanation of the ages of the world that did not emphasise invasion or prognosticate the end would have satisfied the needs of educated clerics such as Wulfstan of Worcester as well as those less well-versed in the complexities of sacred history and eschatology.

\footnotetext{
${ }^{28}$ Lionarons proposes that Wulfstan's concern with the Final Days continued until the end of his life in her chapter 'Wulfstan's Eschatology' (2010, 43-74). I would argue that Wulfstan remained concerned with the end times, but was arguably less occupied with pinpointing the precise moment that the end would arrive.
} 


\section{Conclusions}

The various filiations of the six ages indicate that this topic enjoyed substantial and enduring interest throughout the Anglo-Saxon period. Short and informative encyclopaedic texts might be viewed as dully factual and intellectually prosaic. Studies such as Napier's 'Altenglische Kleinigkeiten' (1883, 1-10) and Schröer (1888, $\mathrm{xix}-\mathrm{xxi}$ ), wherein it is implied that the CCCC 178 note is nur ein kleiner Nachtrag, have historically reinforced this idea. However, minor variations such as the replacement of the note in Cotton Vespasian B. vi with one based on political leaders or the augmentation of Napier LXII that omits the exile, in fact, convey significant choices on the part of the authors and compilers of these texts. How Anglo-Saxon scholars understood and articulated the sex aetates mundi at different points in this period offers insights into the historiographical, theological and political concerns of the time. In the wake of AD 1000, the redactor of Napier LXII reformulated the six ages into a historiographical schematisation which is divorced of overly precise numerological calculations. The omission of a tally for each of the six ages might suggest oversight of Bede's meticulous chronological recalculation of annus mundi; however, it emphatically embodies both Augustine's and Bede's spiritual understanding of the six ages as an eschatological framework for understanding Heilsgeschichteparticularly its final future events-as opposed to an untenable but allegorically appropriate world age of c.6,000 years. The text seems to function as a means of assisting the Anglo-Saxons to understand the grand scheme of Heilsgeschichte and their place within it. ${ }^{29}$ Although the note in CCCC 178 represents a final addition to the manuscript, the position of Napier LXII in CCCC 201 and Hatton 113 verifies that it was deliberately selected to complement the cosmological materials contained therein. That such a distinctive treatment of this topic was included as an integral part of these compendia indicates a sharp pivot in eleventh-century thought concerning the six ages, and its edifying and spiritual value. The six ages of the world was a polyvalent interpretative tool that did not simply rest within the purview of learned scholars, but was critical to the social, political and religious concerns of late Anglo-Saxon England.

Acknowledgements I would like to thank Kees Dekker and Christine Rauer for kindly reading drafts of this article and for providing many helpful comments.

Funding Open Access funding provided by the IReL Consortium.

\section{Declarations}

Conflict of interest I confirm that there are no conflicts of interest in terms of financial support. I confirm that the manuscript has not been submitted elsewhere. No human or animal subjects are involved in this study. Issues of informed consent are not relevant to this study. There are no ethical issues associated with this submission. This submission is an original piece of research that is my own work. I confirm that this submission is entirely compliant with the Committee on Public Ethics guidelines regarding publications.

${ }^{29}$ Dekker discusses how such texts reinforce the relationship of the Anglo-Saxons to the history of the Old Testament Jewish people $(2007,310)$. 
Open Access This article is licensed under a Creative Commons Attribution 4.0 International License, which permits use, sharing, adaptation, distribution and reproduction in any medium or format, as long as you give appropriate credit to the original author(s) and the source, provide a link to the Creative Commons licence, and indicate if changes were made. The images or other third party material in this article are included in the article's Creative Commons licence, unless indicated otherwise in a credit line to the material. If material is not included in the article's Creative Commons licence and your intended use is not permitted by statutory regulation or exceeds the permitted use, you will need to obtain permission directly from the copyright holder. To view a copy of this licence, visit http://creativecommons.org/licen ses/by/4.0/.

\section{References}

Anlezark, D. (2006). Reading 'the story of Joseph' in MS Cambridge Corpus Christi College 201. In H. Magennis \& J. Wilcox (Eds.), The power of words. Anglo-Saxon studies presented to Donald G. Scragg on his seventieth birthday (pp. 61-94). West Virginia University Press.

Anlezark, D. (2010). Understanding numbers in London, British Library, Harley 3271. Anglo-Saxon England, 38, 137-155.

Bethurum, D. (1957). The homilies of Wulfstan. Oxford University Press.

Bremmer, R. H., Jr. (2003). The final countdown: Apocalyptic expectations in Anglo-Saxon charters. In G. Jaritz \& G. Moreno-Riaño (Eds.), Time and eternity: The medieval discourse (pp. 501-514). International Medieval Research 9. Brepols.

Budney, M. (1997). Insular, Anglo-Saxon, and early Anglo-Norman manuscript art at Corpus Christi College, Cambridge. Medieval Institute Publications.

Chambers, R. (1959). Beowulf: An introduction to the study of the poem, with a discussion of the stories of Offa and Finn. With a supplement by C. L. Wrenn (3rd ed.). Cambridge University Press.

Clayton, M. (2005). Ælfric's De auguriis and Cambridge, Corpus Christi College 178. In K. O’Brien O'Keeffe \& A. Orchard (Eds.), Latin learning and English lore: Studies in Anglo-Saxon literature for Michael Lapidge (Vol. 2, pp. 376-394). University of Toronto Press.

Cubitt, C. (2015). Apocalyptic and eschatological thought in England around the year 1000. Transactions of the RHS, 25, 27-52.

Davis, C. (1992). Cultural assimilation in the Anglo-Saxon royal genealogies. Anglo-Saxon England, 21, 23-36.

Dekker, K. (2007). Anglo-Saxon encyclopaedic notes: Tradition and function. In R. Bremmer \& K. Dekker (Eds.), Foundations of learning: The transfer of encyclopaedic knowledge in the early Middle Ages (pp. 279-315). Mediaevalia Groningana NS 9. Peeters.

Dekker, K. (2012). The vernacularization of Anglo-Saxon encyclopaedic notes. In L. Chardonnens \& K. Carella (Eds.), Secular learning in Anglo-Saxon England: Exploring the vernacular. Amsterdamer Beiträge zur älteren Germanistik, 69 (pp. 65-95). Rodopi.

Dekker, K. (2013). The organisation and structure of Old English encyclopaedic notes. Filologia Germanica, 5, 95-130.

Dekker, K. (2019). Encyclopaedic notes as micro-texts: Contextual variation and communicative function. In U. Lenker \& L. Kornexl (Eds.), Anglo-Saxon micro-texts. Buchreihe der Anglia, 67 (pp. 203-224). De Gruyter.

Duncan, E. (1999). Fears of the Apocalypse: The Anglo-Saxons and the coming of the first millennium. Religion and Literature, 31(1), 15-23.

Estes, H. (2012). Anglo-Saxon biblical lore: An edition. Review of English Studies, 93(6), 623-651.

Förster, M. (1925). Die Weltzeitalter bei den Angelsachsen. In Neusprachliche Studien: Festgabe Karl Luick zu seinem sechzigsten Geburtstage dargebracht von Freunden und Schülern (pp. 183-203). N. G. Elwert.

Fox, M. (2018). Vercelli homilies XIX-XXI, the Ascension Day homily in Cambridge, Corpus Christi College 162, and the catechetical tradition from Augustine to Wulfstan. In S. Zacher \& A. Orchard (Eds.), New readings in the Vercelli Book (pp. 254-279). Toronto Anglo-Saxon Series. University of Toronto Press.

Foxhall-Forbes, H. (2019). Making books for pastoral care in late eleventh-century Worcester: Oxford, Bodleian Library, Junius 121 and Hatton $113+114$. In P. Clarke \& S. James (Eds.), Pastoral care in medieval England: Interdisciplinary approaches (pp. 29-66). Routledge. 
Gneuss, H., \& Lapidge, M. (2015). Anglo-Saxon manuscripts: A bibliographical handlist of manuscripts and manuscript fragments written or owned in England up to 1100. Toronto Anglo-Saxon Series 15. University of Toronto Press.

Godden, M. (1979). Alfric's Catholic Homilies: The second series. Early English Text Society, SS 5. Oxford University Press.

Godden, M. (1994). Apocalypse and invasion in late Anglo-Saxon England. In M. Godden, D. Gray, \& T. Hoad (Eds.), From Anglo-Saxon to early Middle English: Studies presented to E. G. Stanley (pp. 130-162). Oxford University Press.

Hill, J. (1992). Ælfric and Smaragdus. Anglo-Saxon England, 21, 203-237.

Hill, T. D. (1987). The myth of the ark-born son of Noe and the West-Saxon royal genealogical tables. Harvard Theological Review, 80(3), 379-383.

Jost, K. (1950). Wulfstanstudien. Schweizer anglistische Arbeite 23. Francke.

Ker, N. R. (1957). Catalogue of manuscripts containing Anglo-Saxon. Clarendon Press.

Kleist, A. (2009). Assembling Ælfric: Reconstructing the rationale behind eleventh- and twelfth-century compilations. In H. Magennis \& M. Swan (Eds.), A companion to Alfric (pp. 369-398). Brill.

Lenker, U., \& Kornexl, L. (Eds.). (2019). Anglo-Saxon micro-texts. Buchreihe der Anglia, 67. De Gruyter. Lionarons, J. T. (2010). The homiletic writings of Archbishop Wulfstan: A critical study. D. S. Brewer.

Liuzza, R. (1994). The Old English version of the Gospels. Early English Text Society, OS 304. Oxford University Press.

Meaney, A. (1989). Scyld Scefing and the dating of Beowulf-again. Bulletin of the John Rylands Library, 71(1), 7-40.

Napier, A. (1883). Wulfstan: Sammlung der ihm zugeschriebenen Homilien nebst Untersuchungen über ihre Echtheit. Weidmann.

Ó Cróinín, D. (1983). The Irish Sex aetates mundi. Dublin Institute for Advanced Studies.

Pons-Sanz, S. (2007). Norse-derived vocabulary in late Old English texts: Wulfstan's works, a case study. John Benjamins.

Powell, K. (2008). Viking invasions and marginal annotations in CCCC 162. Anglo-Saxon England, 37, 151-171.

Redgate, A. (2014). Religion, politics and society in Britain, 800-1066. Routledge.

Rudolf, W. (2001). Style and composition of Napier XVIII-a matter of person or a matter of purpose? In T. Honegger (Ed.), Authors, heroes and lovers: Essays in medieval English literature and language. Selected papers from the Studientage zum englischen Mittelalter SEM 1 and 2 (pp. 107-149). Lang.

Schröer, A. (1988). Die angelsächsischen Prosabearbeitungen der Benediktinerregel. Georg Wigand.

Skeat, W. (1874). The Gospel according to Saint Luke: In Anglo-Saxon, Northumbrian, and Old Mercian versions, synoptically arranged with collations exhibiting all the readings of all the MSS. Cambridge University Press.

Stoneman, W. (1987). Another Old English note signed 'Coleman.' Medium Avum, 56(1), 78-82.

Swanton, M. (1996). An Anglo-Saxon chronicle. Exeter University Press.

Thorpe, B. (1846). The homilies of the Anglo-Saxon church: The first part, containing the Sermones Catholici or Homilies of Alfric (Vol. 2). The Ælfric Society.

Toswell, M. J. (2020). Genre and the Dictionary of Old English. In M. C. Hyer (Ed.), Old English lexicology and lexicography: Essays in honour of Antonette DiPaolo Healey (pp. 229-244). University of Toronto Press.

Tristram, H. (1985). Sex aetates mundi: Die Weltzeitalter bei den Angelsachsen und den Iren: Untersuchungen und Texte. Anglistische Forschungen 165. Carl Winter.

Wallis, F. (1999). Bede: The reckoning of time. Translated Texts for Historians 29. Liverpool University Press.

Wanley, H. (1705). Librorum veterum septentrionalium catalogus. Sheldonian Theatre.

Wilcox, J. (1992). The dissemination of Wulfstan's homilies: The Wulfstan tradition in eleventh-century vernacular preaching. In C. Hicks (Ed.), England in the eleventh century: Proceedings of the 1990 Harlaxton symposium (pp. 199-217). Watkins.

Wilcox, J. (2000). Wulfstan and the twelfth century. In M. Swan \& E. Treharne (Eds.), Rewriting Old English in the twelfth century. Cambridge University Press.

Publisher's Note Springer Nature remains neutral with regard to jurisdictional claims in published maps and institutional affiliations. 